\title{
$\mathrm{PO}$ 필름 피복 온실의 수량 증대 및 에너지 절감 효과
}

\author{
문종필 $^{*} \cdot$ 박석호 $^{2} \cdot$ 김진구 $^{1} \cdot$ 이재한 ${ }^{1} \cdot$ 강연구 $^{3} \cdot$ 임미영 $^{4} \cdot$ 김혜민 $^{4}$
}

${ }^{1}$ 국립원예특작과학원 시설원예연구소 연구사, ${ }^{2}$ 국립원예특작과학원 시설원예연구소 연구관,

${ }^{3}$ 국립농업과학원 농업공학부 연구사, ${ }^{4}$ 국립원예특작과학원 시설원예연구소 박사후 연구원

\section{Yield Increase and Energy Saving Effect on Plastic Greenhouse Covered with Polyolefin Film}

\author{
Jong Pil Moon ${ }^{1 *}$, Seok Ho Park ${ }^{2}$, Jin Gu Kim ${ }^{1}$, Jae Han Lee ${ }^{1}$, Youn Koo Kang ${ }^{3}$, \\ Mi Young $\mathrm{Lim}^{\mathbf{4}}$, and Hye Min Kim ${ }^{4}$ \\ ${ }^{1}$ Researcher, Protected Horticulture Research Institute, NIHHS, RDA, Haman 52054, Korea \\ ${ }^{2}$ Senior Researcher, Protected Horticulture Research Institute, NIHHS, RDA, Haman 52054, Korea \\ ${ }^{3}$ Researcher, Department of agricultural Engineering, NAS, RDA, Jeonju 54875, Korea \\ ${ }^{4}$ Postdoctoral fellow, Protected Horticulture Research Institute, NIHHS, RDA, Haman 52054, Korea
}

\begin{abstract}
This study was carried out to investigate the effect of PO film on the increase of crop yield and energy saving through PO and PE film greenhouse application and comparison test. As a experimental greenhouse, two single span greenhouses $(1-1 \mathrm{~W})$ and two double span greenhouses $(1-2 \mathrm{~W})$ were used. During winter season, PO film $(0.15 \mathrm{~mm}$ outer layer, $0.10 \mathrm{~mm}$ inner layer) was used as a covering material of greenhouse in double layers for double-span (B15) and single-span(B21), and PE film used for double-span (B15), and single-span (B23) as a control. The experimental vegetable was tomato(Solanum lycopersicum L.) cultivated in soil and the cultivar of that was 'Happiness'. That was cultivated from December 3, 2019 to April 30, 2020. The temperature at night inside the greenhouse was maintained at $15^{\circ} \mathrm{C}$, and the side and roof windows were opened to maintain $23 \sim 24^{\circ} \mathrm{C}$ during the day. As a result, this study showed that the yield in single-span greenhouse(B21) covered with a PO film increased $20 \%$ and that in double-span greenhouse (B16) increased by $9 \%$ compared to the greenhouse covered with a PE film (B23, B15). Fuel consumption of the single-span greenhouse (B21) with the cover of PO film was reduced by $12.4 \%$ and that of double-span greenhouse was done by $11.5 \%$ compared to that of the PE film greenhouse (B23, B15) without any difference between them in growing state.
\end{abstract}

Additional key words : heating cost saving, insulation effect, Solar radiation increase

\section{서 론}

우리나라의 온실면적은 2018년 현재 53,274ha이며 가온온 실은 $17,399 \mathrm{ha}$ 로서 온실 전체면적의 $32.7 \%$ 를 차지하고 있다 (MAFRA, 2019). 난방을 하는 온실면적은 2005년에 $12,733 \mathrm{ha}$ 로서 $24.5 \%$ 를 차지하였고 2010 년에는 $15,591 \mathrm{ha}$ 로 $30 \%$ 를 넘어서 2018년 현재에는 $32.7 \%$ 를 차지하고 있다 (MAFRA, 2019). 근래에 난방온실의 증가추세가 많이 둔화 되었지만 난방온실 점유율이 점차로 증가하는 것은 작물을 연 중 재배하고자 하는 시설 재배 농업의 특성으로 보여진다. 이

*Corresponding author: jpmoon2002@korea.kr Received September 11, 2020; Revised October 12, 2020; Accepted October 13, 2020
런 특성은 시설원예농가의 생산비 중 난방비가차지하는 비율 이 30 40\%(Lee 등, 2011)로서 고추가 $38 \%$, 토마토 $31 \%$, 파 프리카 $38 \%$, 국화 $26 \%$ 장미가 $42 \%$ 로서 네덜란드가 $10 \sim 20 \%$ 수준인 것에 비교하면 분명히 농가경영에 부담이 되고 있으며 난방비의 비중을 2022년까지 20 30\%로 줄이고자 하는 농림 축산식품부의 정책에서도 분명하게 드러나고 있다. 또한 난 방연료중 유류가 차지하는 비중이 2018년 현재 $84 \%$ 를 차지 하고 있고 온실의 $90 \%$ 이상이 10 년 이상 노후화된 시설로 보 온성에 다양한 문제가 발생되고 있다. 또한 채소 비닐하우스 의 $86 \%$ 는 단동온실로 보온비가 낮고 단열 미비로 가온에 불 리한 실정이다. 이러한 상황을 극복하기 위해서는 시설재배 농가에서 주로 사용되고 있는 유류사용을 줄이고 열손실을 최 소화하여 난방비용을 절감할 수 있는 에너지 절감기술 개발이 
매우 중요하다(Ryou 등, 2008). 온실의 열손실은 대개 피복재 표면을 통하여 일어나게 되는데, 이때 외부로 전달되는 열이 $60 \sim 100 \%$ 가 되므로 겨울철 온실 난방비를 줄이기 위하여 온 실 표면적을 통한 열손실을 최소화해야 한다(Shin 등, 2015). 한편 농가의 경제적 이익을 증진하기 위해서는 생산성을 증 가시켜야 하는 측면이 있는데 난방비용을 절감하는 것과 상충 되는 면이 있어 생산성을 증가시키면서도 난방비가 많이 들지 않는 기술개발이 필요하다. 이러한 기술개발에 온실 피복 및 보온재에 대한 기술개발이 중요시되고 있다(Jin 등, 2018, 2019; Yun 등, 2019). 온실 피복재는 작물 생장 및 수확에 필 수적인 에너지를 공급하는 햇빛을 투과시키는 중요한 역할을 한다. 온실에 있어서 햇빛은 광합성유효광량자속밀도(PPFD) 가 감소할 때 광합성효율이 떨어져 수량 및 품질 저하로 이어 지므로(Challa와 Schapendonk, 1984; Cockshull, 1992) 빛 의 강도를 $1 \%$ 감소시키면 작물 수확량이 $1 \%$ 가 감소될 수 있 다고 한다. 이는 햇빛이 광합성 과정에서 식물의 생육량을 형 성하는 화합물이 생성되고 대사과정에 필요한 에너지로 사용 되기 때문이다(Kwon 등, 2012). 특히 Polyolefin 필름(이하 $\mathrm{PO}$ 필름 표기)이 최근 투명성과 보온성이 우수하여 지중가온 을 통한 참외재배 시 보온터널의 피복재로 사용하여 수량성 및 품질 증대를 확인하였고(Shin 등, 1999 ; Shin 등, 2009) 2014년 PO필름 사용이 2010년에 비해 3.4배로 증가한 것을 보고하였으며(Shin 등, 2016) PO필름의 우수성이 생산성 증 대 및 품질개선에는 효과적인 것으로 보고되고 있다. 그러나 에너지 절감측면에서 그 효과를 구체적으로 제시한 연구결과 는 그리 많지 않다.

그러므로 본 연구에서는 $\mathrm{PO}$ 필름의 생산성 및 보온성을 관 행적으로 많이 사용되고 있는 Polyethylene 필름(이하 PE필 름 표기)과 비교하였다. 또한 주간에 $\mathrm{PO}$ 필름의 투광성 증대 에 의한 $\mathrm{PE}$ 필름 대비 생산성 증대와 지상부 야간 난방시 $\mathrm{PO}$ 필름의 보온성 증대에 의한 열손실 저감 효과를 온실 형태(단 동 및 연동형)에 따라 검증하고자 하였다.

\section{재료 및 방법}

\section{1. $\mathrm{PE}, \mathrm{PO}$ 필름 시험온실의 조성}

\section{1 단동 온실}

$\mathrm{PE}$ 필름 및 $\mathrm{PO}$ 필름의 단동온실에서의 에너지 절감효과를 비교하기 위하여 경남 함안군 소재 시설원예연구소 단동형 온 실(1-1S, 동서 방향)을 $\mathrm{PE}$ 필름 온실(B23동)과 $\mathrm{PO}$ 필름 온실 (B21동)로 각각 조성하였다. 온실의 시설규모는 폭 $7.7 \mathrm{~m}$, 길 이 $30 \mathrm{~m}$, 측고 $1.5 \mathrm{~m}$, 동고 $3.8 \mathrm{~m}$ 이다. 시험온실의 난방기 용량 선정을 위해 최대난방부하는 식(1)(NIAS, 2010)을 이용하여
계산하였다. 비닐피복온실에 다겹보온커튼(5겹 : 마트지+PE 폼+화학솜4온스+부직포 $40 \mathrm{~g}+$ 마트지)을 보온재로 사용하였 으며 열절감률은 이중피복 시 $45 \%$, 설계 외기온은 진주지방 의 TAC $5 \%\left(20\right.$ 년 빈도) 최저기온인 $-10.5^{\circ} \mathrm{C}$, 지중온도 -2 . $1^{\circ} \mathrm{C}$, 온실 난방설정온도는 $15^{\circ} \mathrm{C}$ 를 설계인자로 하여 산정하 였다.

$$
\begin{aligned}
& Q_{g}=\left[A_{g}\left(Q_{t}+Q_{v}\right)+A_{s} \cdot Q_{s}\right] F_{w}= \\
& {\left[A_{g}\left(H_{t}\left(T_{s}-T_{o}\right)\left(1-F_{r}\right)+H_{v}\left(T_{s}-T_{o}\right)\right)+\right.} \\
& \left.A_{s}\left(T_{s}-T_{g}\right)\right] F_{w}
\end{aligned}
$$

여기서 $Q_{g}$ : 최대난방부하 $(\mathrm{W}), A_{g}$ : 시설 피복면적 $\left(\mathrm{m}^{2}\right), Q_{t}$ : 관 류전열부하 $\left(\mathrm{W} / \mathrm{m}^{2}\right), Q_{v}$ : 환기전열부하 $\left(\mathrm{W} / \mathrm{m}^{2}\right), A_{s}$ : 시설 바닥 면적 $\left(\mathrm{m}^{2}\right), Q_{s}$ : 지중전열부하 $\left(\mathrm{W} / \mathrm{m}^{2}\right), F_{w}$ : 풍속보정계수, $H_{t}$ : 관류열전달계수 $\left(\mathrm{W} / \mathrm{m}^{2} \cdot{ }^{\circ} \mathrm{C}\right), T_{s}$ : 난방설정온도 $\left({ }^{\circ} \mathrm{C}\right), T_{o}$ : 설계 외기온 $\left({ }^{\circ} \mathrm{C}\right), T_{g}$ : 지중온도 $\left({ }^{\circ} \mathrm{C}\right) F_{r}$ : 보온재 열절감률, $H_{v}$ : 환기 전열계수 $\left(\mathrm{W} / \mathrm{m}^{2} \cdot{ }^{\circ} \mathrm{C}\right)$

상기의 계산에 의해 시험 단동온실 1 동의 공간난방을 위한 최대난방부하는 $37,000 \mathrm{kcal} / \mathrm{h}$ 로 계산되었으며 산정된 최대 난방부하에 충분히 대응할 수 있도록 $60,000 \mathrm{kcal} / \mathrm{h}$ 의 등유온 풍기 및 난방 덕트를 설치하였다. 시험온실의 피복형태는 이 중피복형태로서 외피는 두께 $0.15 \mathrm{~mm}$ 의 피복재를 사용하였 고 내피는 $0.10 \mathrm{~mm}$ 를 사용하였다. 보온재로는 5 겹의 다겹보 온커튼을 사용하였다. 다겹보온커튼은 1 중골조와 2 중골조사 이를 보온할 수 있도록 2중골조에 중앙귄취식으로 설치하였 다. 주간에는 다겹보온재 및 이중피복재를 지붕 중앙부(종도 리 근접부)에 권취하도록 하고 이를 개방하여 1 중의 피복재만 이 지붕부를 피복하도록 하여 광합성에 필용한 광량을 충분히 확보할 수 있도록 운영하였다. 야간에는 이중골조에 설치되 어 있는 피복재 및 보온재가 온실 상부 및 측면을 덮어 야간 난 방시 충분한 보온이 이루어 질 수 있도록 하였다. 또한주간에 는 온실내부가 $27^{\circ} \mathrm{C}$ 이상이 되면 외피(1중 피복 필름) 측장이 열리고 자연환기가 이루어지도록 하였고 온실내부 $23 \sim 24^{\circ} \mathrm{C}$ 가 되도록 관리하였다. 또한 $23^{\circ} \mathrm{C}$ 이하가 되면 외피 측장이 닫 히도록 설정하였다. 내피(2중 피복 필름)는 오후 5 시에 닫았 으며 오후 5 시 30 분에 다겹보온커튼이 닫히도록 하였다. 야간 에는 온실내부온도가 $15^{\circ} \mathrm{C}$ 가 유지될 수 있도록 난방기 설정 온도를 $15^{\circ} \mathrm{C}$ 로 운영하였다. 아침 8 시에 다겹보온커튼이 열리 고 9 시에 2 중 피복 필름이 열리도록 운영하였으며 피복 및 보 온재의 온실 내 설치형태는 Figs. 1. 2와 같다. 


\section{2 연동 온실(2연동)}

$\mathrm{PE}$ 및 $\mathrm{PO}$ 필름의 연동온실(2연동)에서의 에너지 절감효과 를 비교하기 위하여 시설원예연구소의 2 연동의 온실(1-2W, 남북 방향)을 $\mathrm{PE}$ 필름 온실(B15동)과 $\mathrm{PO}$ 필름 온실(B16동)로 각각 조성하였다. 온실의 시설규모는 폭 $8 \mathrm{~m}$, 길이 $30 \mathrm{~m}$, 측고 $3.1 \mathrm{~m}$, 동고 $5.8 \mathrm{~m}$ 의 온실로서 이중 골조로 된 아치형 표준온실 이다. 최대난방부하를 식(1)을 이용하여 단동온실과 동일한 방법으로 산정한 결과 $86,000 \mathrm{kcal} / \mathrm{h}$ 로 산정되었다. 산정된 최 대난방부하에 충분히 대응할 수 있도록 $100,000 \mathrm{kcal} / \mathrm{h}$ 의 등 유온풍기 및 난방덕트를 설치하였다. 시험온실의 피복형태는 이중피복형태로서 외피는 두께 $0.15 \mathrm{~mm}$ 의 피복재를 사용하 였고 내피는 $0.10 \mathrm{~mm}$ 를 사용하였다. 보온재로는 4겹의 알루 미늄 다겹보온커튼(알루미늄스크린 $95 \%+$ 부직포 $40 \mathrm{~g}+$ 화학 솜4온스+마트지)을 사용하였다. 알루미늄 다겹보온커튼을 2 중골조 아래 중방위치에 수평예인식으로 설치하였다. 주간에 는 알루미늄 다겹보온재 및 이중피복재를 개방하여 일중피복 을 통하여 광합성에 필용한 광량을 충분히 확보 할 수 있도록 운영하였다. 야간에는 이중 피복 필름 및 보온재가 온실 상부 및 측면을 덮어 야간 난방시 충분한 보온이 이루어 질 수 있도 록 하였다. 또한 주간에는 온실내부가 $27^{\circ} \mathrm{C}$ 이상이 되면 천창 (1중 피복 필름)을 열어 최고 $30^{\circ} \mathrm{C}$ 가 유지되면서 자연환기라 이루어지도록 하였다. 또한 온실내부온도는 $23 \sim 24^{\circ} \mathrm{C}$ 가 되도 록 관리하였으며 $23^{\circ} \mathrm{C}$ 이하가 되면 외피의 천창을 닫아 관리

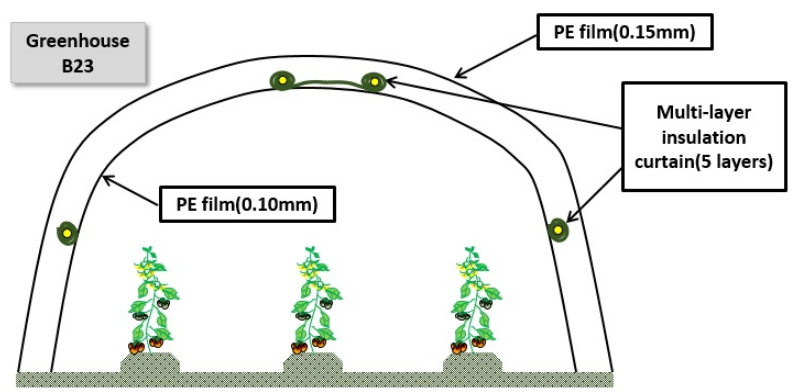

Fig. 1. Cover and insulation curtain in PE film B23).

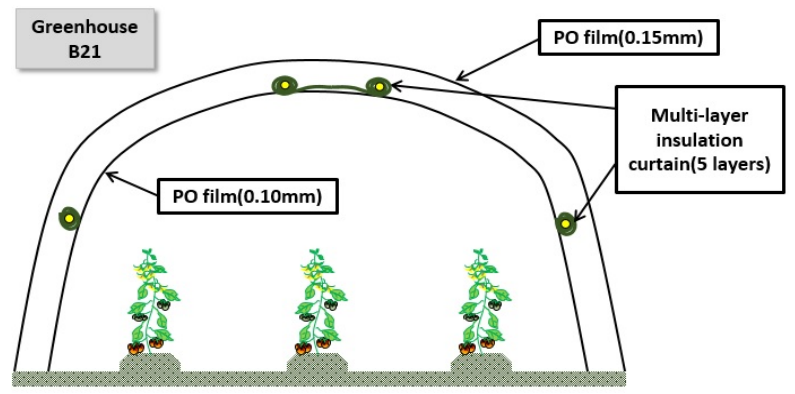

Fig. 2. Cover and insulation curtain in PO film (B21).
하였다. 내피(2중 피복 필름)는 오후 5 시에 닫았으며 일몰 후 일몰 전 50 분에 알루미늄 다겹보온재가 자동으로 닫히도록 운 영하였다. 야간에는 단동온실과 동일한 방법으로 온실내부온 도가 $15^{\circ} \mathrm{C}$ 가 유지될 수 있도록 난방기 설정온도를 $15^{\circ} \mathrm{C}$ 로 운 영하였다. 오전 9 시에 내피(2중 피복 필름)가 개방되도록 하였 으며 피복 및 보온재의 온실 내 설치형태는 Figs. 3, 4와 같다.

\section{2. $\mathrm{PE}, \mathrm{PO}$ 필름 시험온실의 열관류율, 일사량, 온 - 습도 및 연료소비량 측정}

단동 시험온실의 열관류율, 일사량, 온습도를 측정하기 위 하여 온실 중간지점에 열관류율 센서(MF-180, EKO, Japan), 일사량 센서(LightScout solar radiation sensor(36701), SPECTRUM Tech. inc., U.S.A) 및 온습도 센서(HOBO Pro v2, ONSET, U.S.A)를 설치하여 2019년 12월 24일부터 2020 년 4 월 30 일까지 10 분 간격으로 측정하였다. 열관류율 측정은 지붕면의 열관류율을 측정하기 위해 지붕면 종도리와 처마도리 사이의 중간지점인 남쪽면 내측면에 설치하였다. 또한 측면의 열관류율을 측정하기 위해서 측면의 지면으로부 터 $1.7 \mathrm{~m}$ 지점의 남쪽측창부에 측창 열림의 상한지점보다 바 로 윗 지점에 설치하였다. 일사량 센서는 지면으로부터 $1.8 \mathrm{~m}$ 지점의 남북면 양쪽에 2 개를 설치하였으며 15 일 간격으로 평 균 일사량을 분석하였다. 온습도 센서는 온실내부온도를 측 정하기 위해 지면으로부터 $2 \mathrm{~m}$ 위치이며 온실 중앙에 1 개를

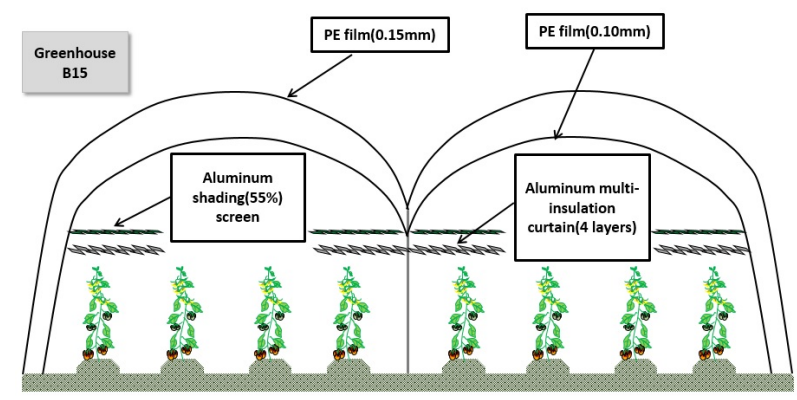

Fig. 3. Cover and insulation curtain in PE film (B15).

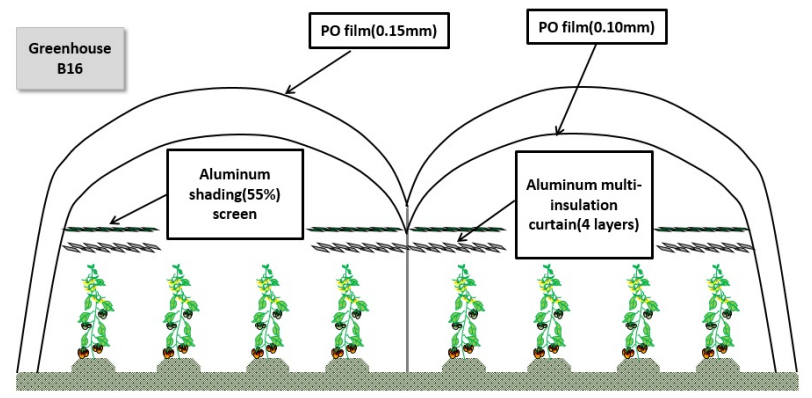

Fig. 4. Cover and insulation curtain in PO film (B16).

Protected Horticulture and Plant Factory, Vol. 29, No. 4, 2020 
설치하였다. 1 중과 2 중 필름 사이의 지붕면과 측면을 측정하 기 위해 2 개를 설치하였으며 모든 계측센서의 설치위치 및 온 실내부는 Figs. 5, 6, 7과 같다. 또한 피복재별 연료소비량을 측정하기 위해 재배기간인 2019년 12월 3 일부터 2020년 4월 30 일까지 난방을 위해 가동되는 온풍난방기의 등유사용량을 측정하기 위해 적산유량계(미소유량계 SSO-8(15A), hanil ins., Korea) 를 연료공급배관에 설치하여 측정하였다.

연동온실의 열관류율을 측정하기 위해 열관류율 센서를 온 실전체의 중간지점에 설치하였다. 시험온실은 2 연동 온실이 어서 지붕면의 열관류율을 측정하기위해 서쪽지붕과 동쪽지 붕면 사이의 곡부로부터 가까운 동쪽과 서쪽의 지붕면의 중간 위치에 열관류율 센서(MF-180, EKO, Japan) 2개를 설치하 였다. 연동온실의 측면 열관류율을 측정하기 위하여 북쪽과 남쪽 측면에 지상으로부터 $2.5 \mathrm{~m}$ 높이에 위치하도록 하여 2 개 의 열관류율을 측정하였다. 일사량 센서(LightScout solar radiation sensor(36701), SPECTRUM Tech. inc., U.S.A)는 지면으로부터 $1.8 \mathrm{~m}$ 지점의 동서면 양쪽에 2 개를 설치하였으 며 단동온실과 동일한 방법으로 분석하였다. 온습도 센서 (HOBO Pro v2, ONSET, U.S.A)는 온실내부 온도를 측정하 기 위해 지면으로부터 $1.8 \mathrm{~m}$ 위치이며 온실 중앙에 1 개를 설치 하였다. 또한 1 중과 2 중 필름 사이의 지붕면과 측면의 온습도
를 측정하기 위해 지붕면 2 개, 측면 2 개를 설치하였으며 연료 소비량도 단동온실과 동일한 방법으로 계측하였다. 모든 계 측센서의 설치위치 및 온실내부는 Fig. $8,9,10$ 과 같다.

\section{3. 토마토 토양 재배}

시험 토양은 미사질 식양토(Silty Clay Loam)로서 2017년 국립농업과학원에서 발행한 작물별 비료사용처방기준에서 제시하는 토마토 시설재배 추천 시비량에 준하여 비료와 퇴비 를 시용하였다(NIAS. 2017). 비료 시용량은 $10 \mathrm{a}$ 당 N-P-K, $11.6-10.3-4.1 \mathrm{~kg}$ 을 기비로, 추비는 10 당 N-P-K, $8.8-0-8.1 \mathrm{~kg}$ 을 2 3회에 걸쳐 시용하였다. 또한 $10 \mathrm{a}$ 당 퇴구비 $2,000 \mathrm{~kg}$, 석 회 $30 \mathrm{~kg}$ 를 기준으로 전량 기비로 투입하였다. 재배실험은 완 숙 토마토 품종인 Solanum lycopersicum L. 'Happiness'( (주)아시아 종묘) 를 2019년 12월 3일에 정식하여 2020년 4월 30 일까지 재배하였다. 정식은 폭 $60 \mathrm{~cm}$ 로 조성된 두둑에 1 줄 심기를 하였으며 재식거리는 $40 \mathrm{~cm}$ 간격으로 두둑 1 열에 73 주씩 정식하였다. 단동온실은 두둑 3 곳을 조성하여 총 220 주 를 정식하였다. 연동온실도 단동온실과 동일하게 두둑 폭을 $60 \mathrm{~cm}$ 로 조성하여 1줄에 88 주를 정식하였고 2 연동 온실에 8 곳의 두둑을 조성하여 700 주를 정식하였다. 관수, 병해충 방제 및 재배관리는 농촌진흥청 표준재배법에 준하여 실시하였다.

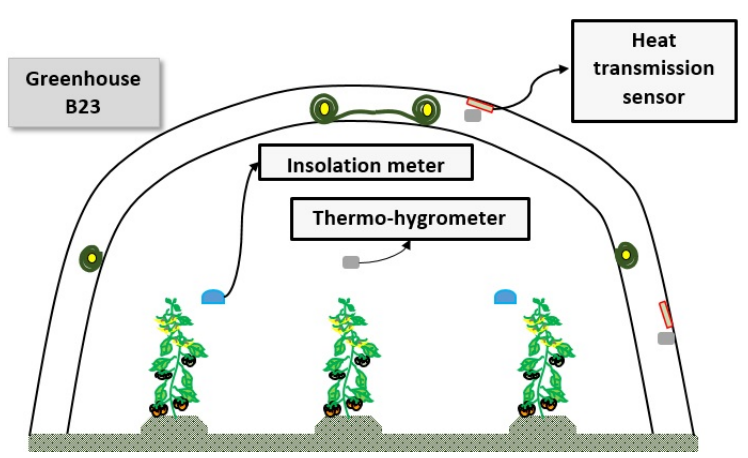

Fig. 5. Sensor location map in PE film (B23).

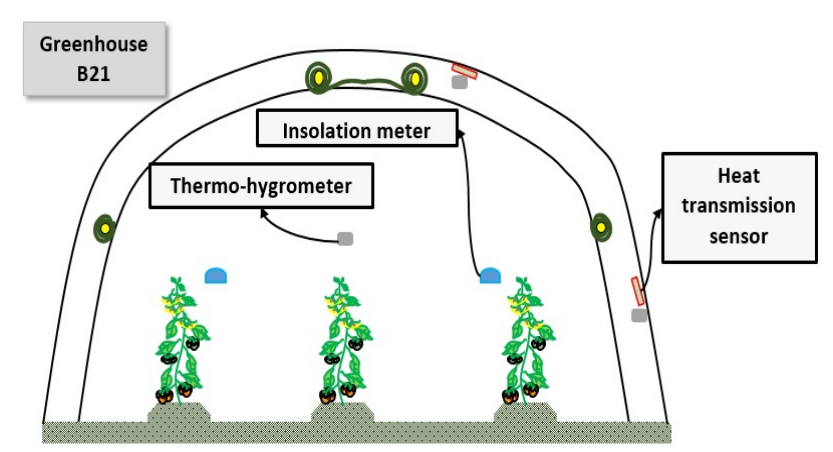

Fig. 6. Sensor location map in PO film (B21).

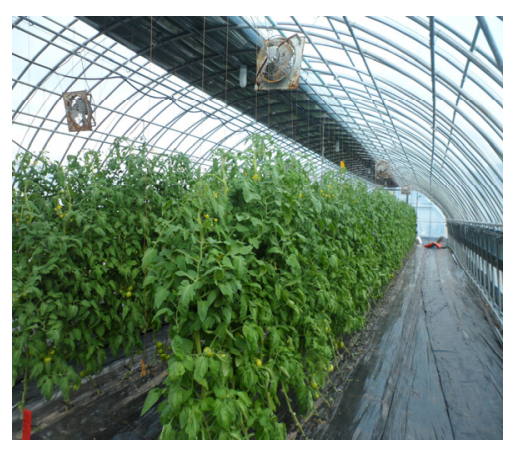

(a)

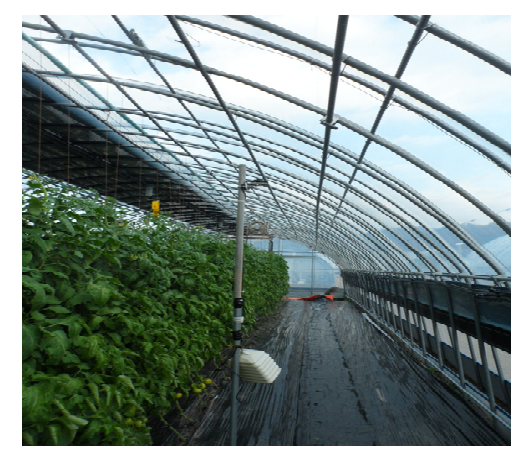

(b)

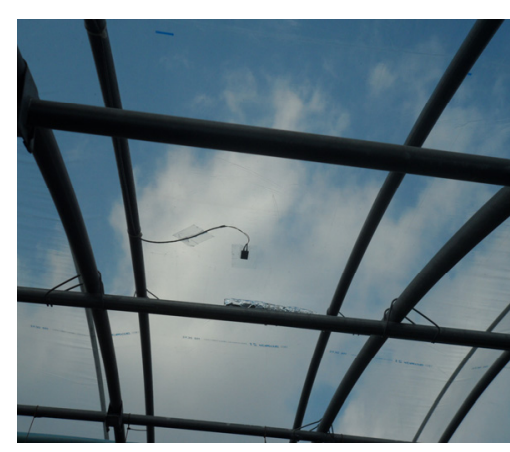

(c)

Fig. 7. Tomato cultivation(a), insolation meter(b) and heat transmittance sensor(c) in a single span greenhouse. 


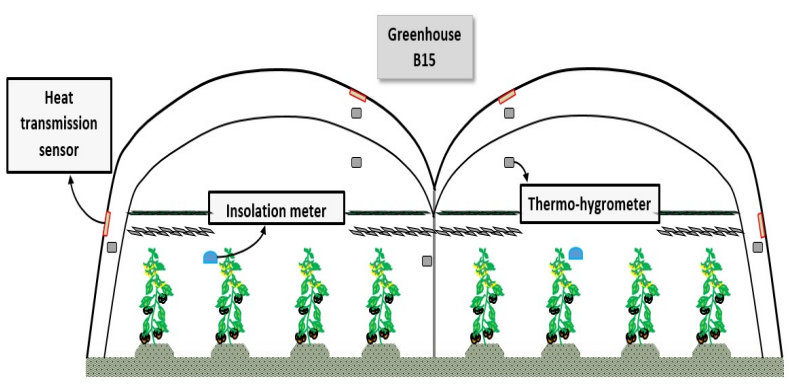

Fig. 8. Sensor location map in PE film (B15).

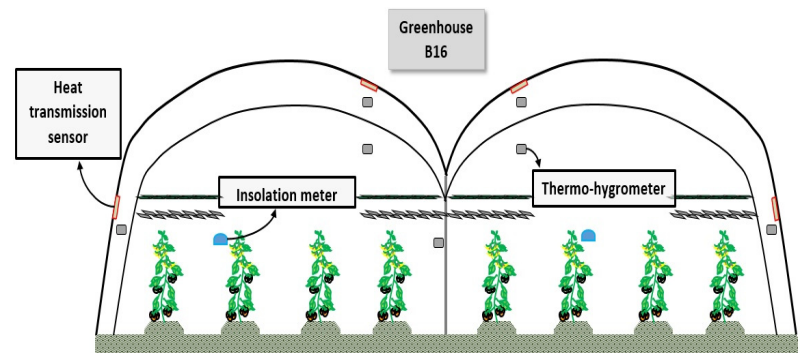

Fig. 9. Sensor location map in PO film (B16).

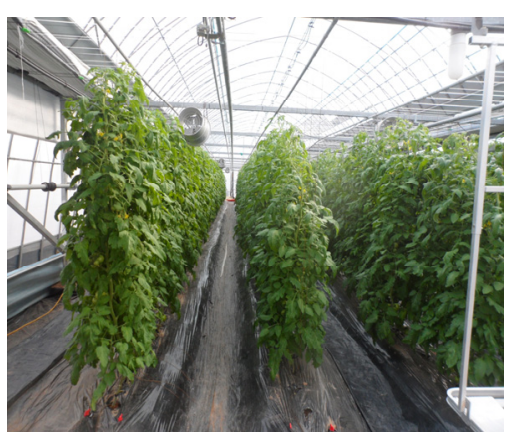

(a)

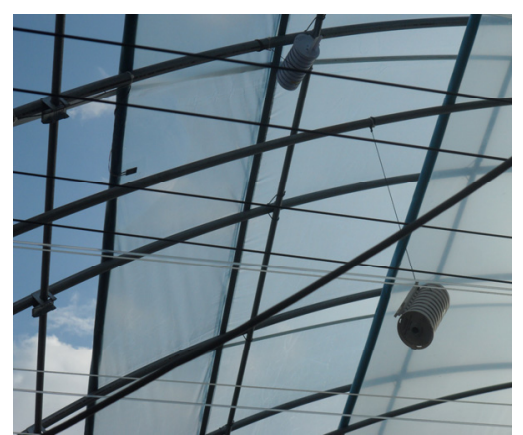

(b)

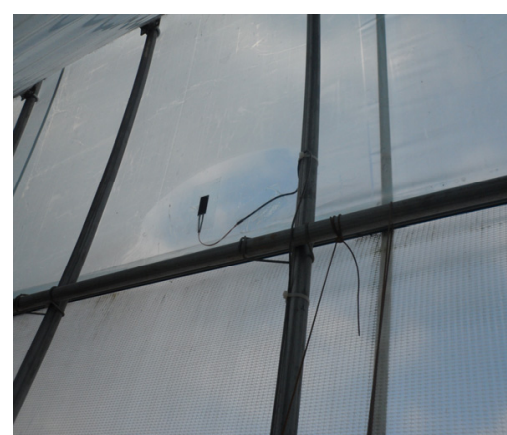

(c)

Fig. 10. Tomato cultivation(a), thermo-hygromenter(b) and heat transmittance sensor(c) in double span greenhouse.

\section{4. 생육량 및 수량조사}

단동온실에서는 Fig. 11 과 같이 3 줄 재배를 하였다. PE필름 피복온실과 $\mathrm{PO}$ 필름 피복온실의 작물 생육상태를 북쪽 측면 (Col. 1), 중앙(Col. 2), 남쪽 측면(Col. 3)에서 재배열 간 비교 하였다. 2019년 12월 3일부터 2020년 4월 30일까지의 재배 기간중 2019년 12월 14일, 2020년 1월20일, 2월 5일, 2월 19 일, 3월 4일, 3 월18일, 4월1 일, 4월14일에 8차례 걸쳐 생육조 사를 실시하였다. 조사항목으로 초장, 경경, 엽장, 엽폭, 엽수, 엽록소 지수(SPAD), 수확량을 조사하였다. 2020년 3월 6일 $\mathrm{PO}$ 필름 온실에서 수확이 가능할 수 있을 정도로 과실이 맺혀 첫번째 수확을 실시하였고 수량조사를 실시하였다. 그 이후 로 3 월 13 일, 3 월 20 일, 3 월 31 일, 4 월 8 일, 4월 22일, 4월 27 일 에 걸쳐 7차례에 걸쳐 5 화방까지 수확량 조사를 실시하였다. 연동온실은 Fig. 12와같이 곡부를 기준으로 한 서쪽온실에서 생육조사를 실시하였다. 1 동의 우측 온실에서 동쪽 측면부터 서쪽으로 col. 1, col. 2, col. 3, col. 4로 나누어 각각 재배열 특 성을 조사하였다. 조사항목, 조사일 및 수확량 조사는 단동온 실과 동일하게 실시하였다. 조사결과에 대한 통계분석은 SAS 프로그램(SAS. ver. 9.2, Institute inc., Cary, NC, USA)을 이 용하여 처리하였으며 Duncan의 다중 검정 방법 및 F-test 방 법으로 분석하였다.

\section{결과 및 고찰}

1. $\mathrm{PE}, \mathrm{PO}$ 필름 시험온실의 열관류율 및 단열층 온도 비교 단동 및 연동온실에서 외피 내측에 부착된 열관류 센서에 의 해 계측된 $\mathrm{PE}$ 필름과 $\mathrm{PO}$ 필름의 열관류율을 측정 개시일인 2020년 1월13일부터 측정 종료일인 4월30일까지의 야간 (18:00 - 익일 05:00)에 10분 간격으로 측정된 열관류율의 평 균값을 산정하였다. 산정결과 온실내외부 온도차에 따른 단 위면적당 피복 및 보온재의 평균 열관류율은 Table 1 과 같다.

Table 1에서 계측된 열관류율 값은 단동온실과 연동온실과 구분하여 분석하고자 한다. 단동온실의 열관류율 값은 온실 내부의 열이 Fig. 13 과 같이 대류 및 복사에 의해 2 중 피복재 (내피), 다겹보온커튼, 공기층, 1 중 피복재(외피)로 전달이 되 는데 단열성능이 우수한 공기층이 1 개만 존재하여 열관류율 값이 연동온실보다 크게 나타난 것으로 판단된다. 연동온실 에서는 온실내부의 열이 Fig. 14와 같이 알루미늄 다겹보온커 튼, 공기층, 2 중 피복재, 공기층, 1 중 피복재에 열이 전달되어 온실 외부로 열이 전달되므로 단열층 역할을 하는 공기층이 2 개가 존재하여 그 단열효과가 큰 것으로 판단된다.

또한 동일한조건을 가지고 있는 경우 동일한 형태의 온실 내에서의 $\mathrm{PE}$ 필름과 $\mathrm{PO}$ 필름의 특성을 분석하기 위하여 경계 층마다의 온도변화를 비교하였다. 2020 년 1 월 16 일 0 시 부터 

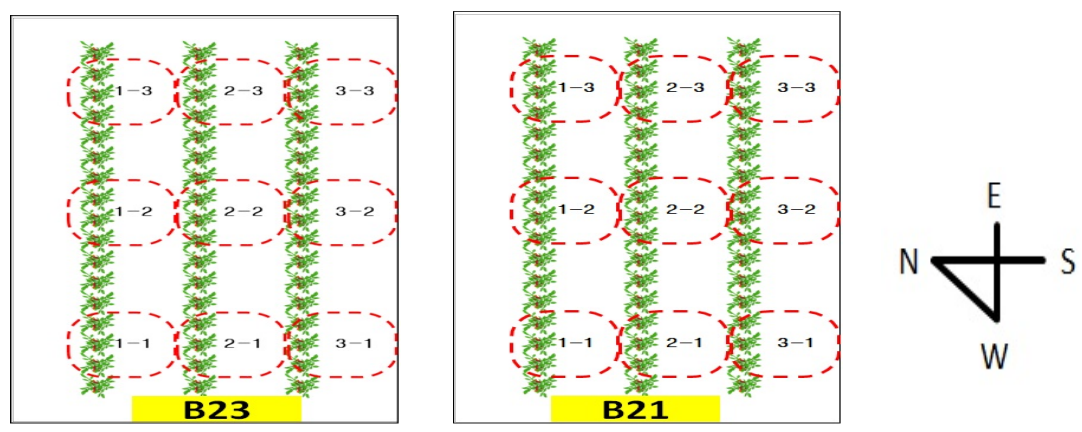

Fig. 11. Sample location map for a growth survey in a single span greenhouse.
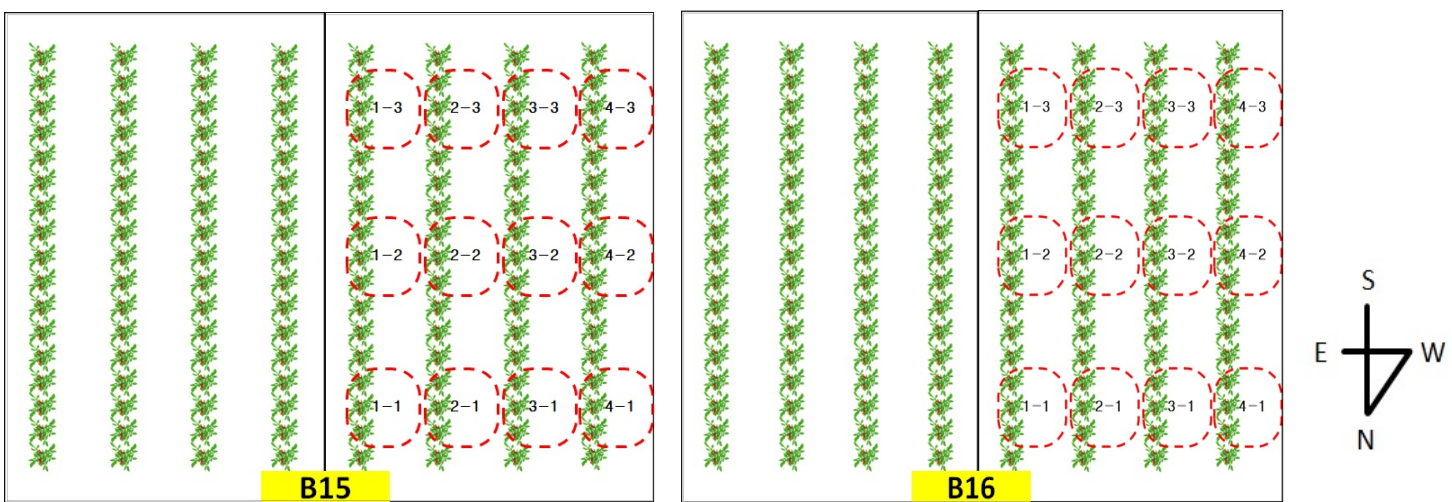

Fig. 12. Sample location map for a growth survey in double greenhouse.

Table 1. Measured Heat transmission rate for cover and insulation combination.

\begin{tabular}{cccccc}
\hline \hline \multirow{2}{*}{ Greenhouse type } & \multicolumn{3}{c}{ Cover and insulation material } & Heat transmission & $\begin{array}{c}\text { Temp. difference } \\
\text { rate }\left(\mathrm{W} / \mathrm{m}^{2} \cdot{ }^{\circ} \mathrm{C}\right)\end{array}$ \\
\cline { 2 - 4 } between outside and inside $\left({ }^{\circ} \mathrm{C}\right)$
\end{tabular}

${ }^{\mathrm{A}}$ Mean \pm S.D. Value

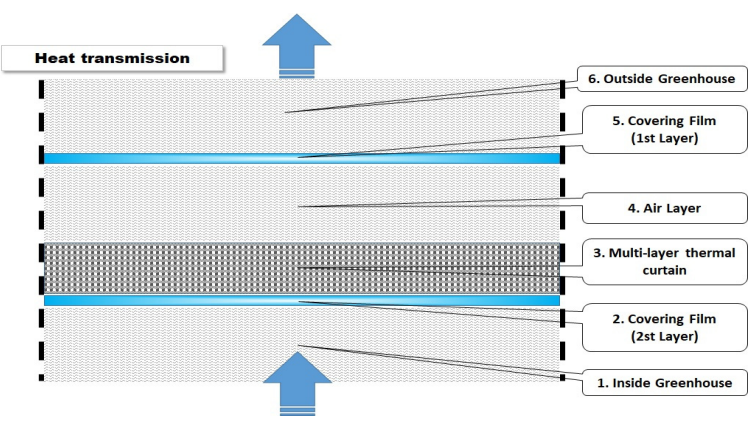

Fig. 13. Heat Transmission process (Single span).

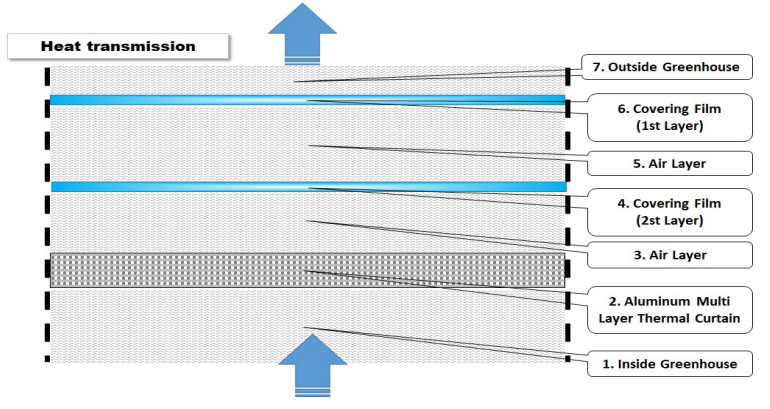

Fig. 14. Heat Transmission process (double span). 
새벽 4시 50 분까지의 온실형태 및 피복재에 따른 시험온실의 경계층 및 온실내외부의 온도변화를 도시하면 Figs. 15,16 과 같다. 단동온실에서는 Fig. 15 에서와 같이 $\mathrm{PO}$ 필름 온실이 외 피의 바로 밑에 층에 있는 1 중과 2 중피복사이의 온도가 $\mathrm{PE}$ 필 름 온실보다약 $0.9^{\circ} \mathrm{C}$ 정도 높아 열손실이 적고 보온효과가 있 는 것는 것으로 나타났다. 또한 단동온실에서 2 중 피복재로 쓰 인 PO필름은 다겹보온커튼과 밀착되어 있어 단열효과가 크 게 나타나지 않은 것으로 나타났다. 연동온실에서는 Fig. 16 과 같이 $\mathrm{PO}$ 필름 온실의 1 중과 2 중 피복재 사이의 온도가 $\mathrm{PE}$ 필름 시험온실보다 약 $1.0^{\circ} \mathrm{C}$ 정도 일정하게 높고 2 중 피복재 와3중 알루미늄 다겹보온커튼 사이의 온도가 $\mathrm{PE}$ 필름 피복온 실보다 $0.5^{\circ} \mathrm{C}$ 정도 높은 것으로 나타나 단동 및 연동온실에서 $\mathrm{PO}$ 필름 피복 온실이 각각의 경계층에서의 열손실 저감 및 보 온 효과에 유리한 것으로 나타났다.

\section{2. 일사량 및 온실 내부 온 - 습도 비교}

2019년 12월 24일부터 2020년 4월 30일까지 10분간격으

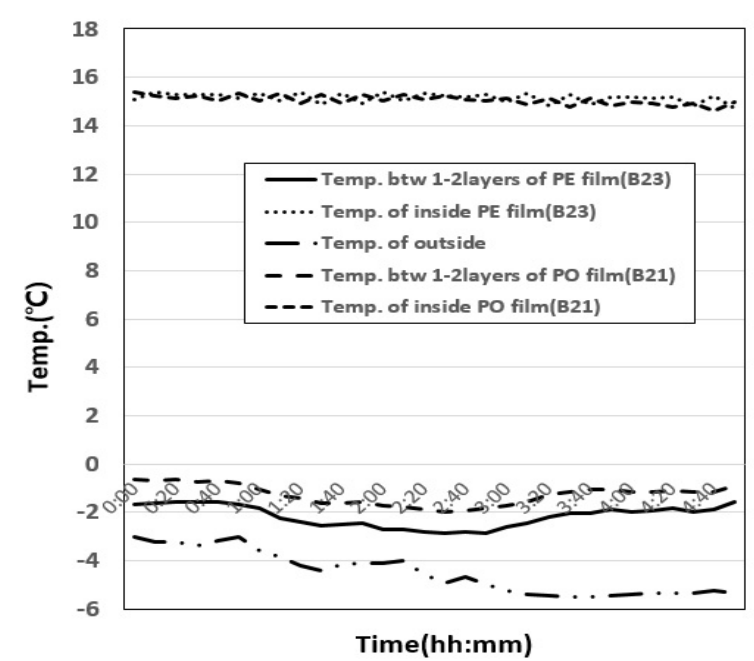

Fig. 15. Temp. comparison btween each layers (single span).
로 일사량을 측정하고 15 일 간격으로 평균 일사량값을 온실 형태 및 피복 형태에 따라 분석한 결과 Fig. 17과 같이 나타났 다. 이러한 결과는 단동온실은 동서방향으로 설치되어 있고 연동온실은 남북방향으로 설치되어 있어 동절기 태양고도가 남쪽으로 치우쳐 있을 때에는 단동온실에 일사량이 많고 남북 방향으로 설치된 연동온실에는 불리하게작용한 것으로 판단 되었다. 시간이 경과되어 계절이 바뀌게 됨에 따라 연동온실 에 일사량이 유리하게 변하는 것으로 나타났다. 전체적인 일 사량의 평균값을 비교해보면 $\mathrm{PO}$ 필름 피복온실의 단동온실 (B21동) 내부 일사량은 시험기간 동안 평균적으로 $195 \mathrm{~W} / \mathrm{m}^{2}$ 이었으며 PE필름 피복 단동온실(B23동) 온실 내부 일사량은 $183 \mathrm{~W} / \mathrm{m}^{2}$ 로서 $\mathrm{PO}$ 필름 온실이 $\mathrm{PE}$ 필름 온실보다 약 $7 \%$ 높은 것으로 조사되었다. 연동온실에서는 $\mathrm{PO}$ 필름 피복온실(B16 동) 온실내부 평균 일사량이 $210 \mathrm{~W} / \mathrm{m}^{2}$ 이었으며 $\mathrm{PE}$ 필름 피복 온실(B15동)의 온실내부 평균일사량이 $187 \mathrm{~W} / \mathrm{m}^{2}$ 으로서 $\mathrm{PO}$ 필름 온실이 $\mathrm{PE}$ 필름 온실보다 약 $11 \%$ 일사량이 많은 것으로 계측되었다. 또한 외부일사량은 시험기간동안 평균적으로

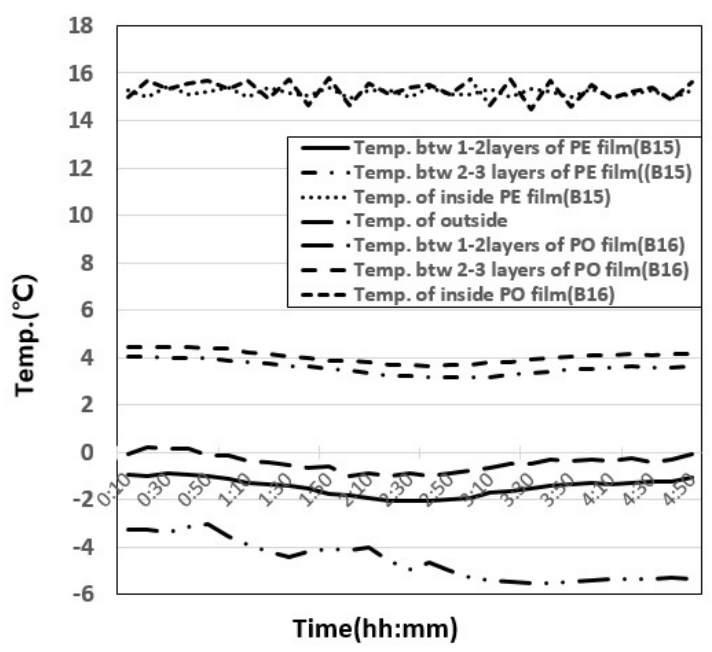

Fig. 16. Temp. comparison btween each layer (double span).

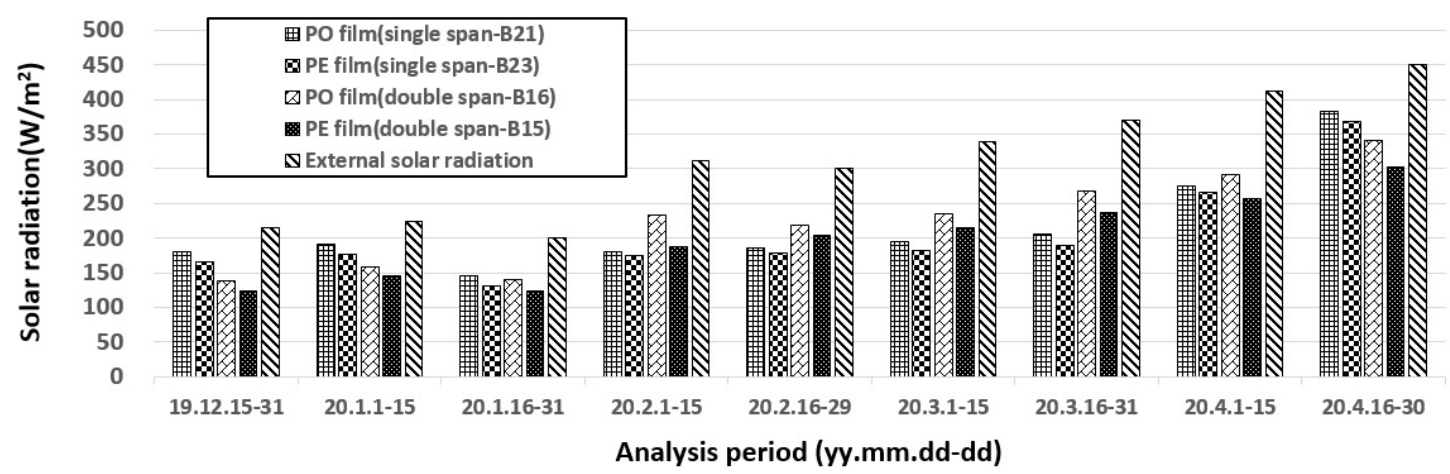

Fig. 17. Solar radiation comparison based on analysis of average value for 15 day intervals. 
$314 \mathrm{~W} / \mathrm{m}^{2}$ 로 계측되어 온실 내부 광투과율은 $\mathrm{PO}$ 필름이 62 67\% , PE필름이 58 60\%를나타났다. 이러한 결과는 Polyolefin계 필름이 Polyethylene계 필름에 비해 투명도가 높아 광투과율이 높았다고 보고한 연구결과(Shin 등, 2009; Shin 등, 2016)와도 일치하였다.

단동온실의 온실내부의 일평균 야간온도는 $\mathrm{PO}$ 필름 온실이 $15.8^{\circ} \mathrm{C}$, 상대습도 $84 \%$ 이었으며 $\mathrm{PE}$ 필름 온실은 $15.5^{\circ} \mathrm{C}$, 상 대습도 $85 \%$ 로 계측되었다. 연동온실에서는 $\mathrm{PO}$ 필름온실이 $16.2^{\circ} \mathrm{C}$, 상대습도 $63 \%$ 이고 $\mathrm{PE}$ 필름 시험온실은 $15.8^{\circ} \mathrm{C}$, 상대 습도 $69 \%$ 로 계측되었다. 시험 온실별 내부 온도 및 상대습도
는 거의 유사한 것으로 나타나 시험온실 난방이 설정온도에 맞춰 정상적으로 잘 수행된 것으로 판단되었다. 또한 온실 내 부의 주야간 일평균 온습도를 측정한 결과 단동온실은 $\mathrm{PE}, \mathrm{PO}$ 필름 온실이 각각 $19.0^{\circ} \mathrm{C}, 19.1^{\circ} \mathrm{C}$, 상대습도는 모두 $75 \%$ 를 나 타냈다. 연동온실은 $\mathrm{PO}$ 필름 온실이 $19.6^{\circ} \mathrm{C}$, 상대습도 $57 \%$ 를 나타냈고 $\mathrm{PE}$ 필름 온실이 $18.8^{\circ} \mathrm{C}$, 상대습도 $63 \%$ 를 나타내어 시험기간의 일평균온도 및 상대습도 역시 거의 유사한 것으로 나타났다. 이러한 결과는 환기(천창 및 측창개폐)에 의한 주간 의 온습도관리가 잘 이루어진것으로 판단되었다.

Table 2. Tomato growth status in a single span greenhouse.

\begin{tabular}{|c|c|c|c|c|c|c|}
\hline \multirow{2}{*}{ Item } & \multicolumn{2}{|c|}{ Treatment } & \multicolumn{4}{|c|}{ Days after planting (Date) } \\
\hline & A & B & $21(‘ 19.12 .24)$ & $64(' 20.2 .5)$ & 106 ('20.3.18) & 133 ('20.4.14) \\
\hline \multirow{9}{*}{$\begin{array}{l}\text { Plant } \\
\text { height } \\
(\mathrm{cm})\end{array}$} & \multirow{3}{*}{$\mathrm{PE}$} & col.1 & $37.3 \pm 4.5 \mathrm{a}^{\mathrm{z}}$ & $147.6 \pm 19.6 \mathrm{a}$ & $269.0 \pm 14.1 \mathrm{a}$ & $327.6 \pm 20.4 \mathrm{a}$ \\
\hline & & col. 2 & $38.6 \pm 2.3 \mathrm{a}$ & $161.3 \pm 2.0 \mathrm{a}$ & $260.6 \pm 9.0 \mathrm{a}$ & $323.6 \pm 11.0 \mathrm{a}$ \\
\hline & & col.3 & $34.6 \pm 6.3 \mathrm{a}$ & $145.6 \pm 15.0 \mathrm{a}$ & $256.3 \pm 14.6 \mathrm{a}$ & $325.0 \pm 19.3 \mathrm{a}$ \\
\hline & \multirow{3}{*}{$\mathrm{PO}$} & col. 1 & $36.0 \pm 7.0 \mathrm{a}$ & $158.0 \pm 2.6 \mathrm{a}$ & $263.6 \pm 13.6 \mathrm{a}$ & $339.5 \pm 7.5 \mathrm{a}$ \\
\hline & & $\operatorname{col} .2$ & $38.6 \pm 1.1 \mathrm{a}$ & $166.3 \pm 7.7 \mathrm{a}$ & $253.0 \pm 7.9 \mathrm{a}$ & $323.0 \pm 6.5 \mathrm{a}$ \\
\hline & & $\operatorname{col} .3$ & $34.6 \pm 3.5 \mathrm{a}$ & $144.3 \pm 9.2 \mathrm{a}$ & $256.6 \pm 16.5 \mathrm{a}$ & $332.0 \pm 24.0 \mathrm{a}$ \\
\hline & \multirow{3}{*}{ F-test ${ }^{y}$} & A & NS & NS & NS & NS \\
\hline & & B & NS & $*$ & NS & NS \\
\hline & & $\mathrm{A} * \mathrm{~B}$ & NS & NS & NS & NS \\
\hline \multirow{9}{*}{$\begin{array}{l}\text { No. of } \\
\text { leaves }\end{array}$} & \multirow{3}{*}{$\mathrm{PE}$} & col.1 & $12.3 \pm 0.5 \mathrm{ab}$ & $28.0 \pm 1.0 \mathrm{a}$ & $37.6 \pm 1.1 \mathrm{a}$ & $45.0 \pm 2.6 \mathrm{bc}$ \\
\hline & & $\operatorname{col} .2$ & $12.6 \pm 0.5 \mathrm{a}$ & $28.3 \pm 1.1 \mathrm{a}$ & $39.6 \pm 1.5 \mathrm{a}$ & $46.3 \pm 1.1 \mathrm{ab}$ \\
\hline & & $\operatorname{col} .3$ & $12.0 \pm 0.0 \mathrm{ab}$ & $27.0 \pm 1.7 \mathrm{a}$ & $37.3 \pm 2.0 \mathrm{a}$ & $47.6 \pm 1.1 \mathrm{a}$ \\
\hline & \multirow{3}{*}{$\mathrm{PO}$} & col.1 & $11.3 \pm 0.5 \mathrm{~b}$ & $26.6 \pm 1.1 \mathrm{a}$ & $39.0 \pm 3.0 \mathrm{a}$ & $43.5 \pm 0.5 \mathrm{c}$ \\
\hline & & col. 2 & $12.0 \pm 1.0 \mathrm{ab}$ & $26.6 \pm 1.5 \mathrm{a}$ & $37.3 \pm 1.1 \mathrm{a}$ & $44.3 \pm 0.5 \mathrm{bc}$ \\
\hline & & $\operatorname{col} .3$ & $12.6 \pm 0.5 \mathrm{a}$ & $26.6 \pm 0.5 \mathrm{a}$ & $38.6 \pm 1.1 \mathrm{a}$ & $44.0 \pm 1.0 \mathrm{bc}$ \\
\hline & \multirow{3}{*}{ F-test } & A & NS & NS & NS & $* *$ \\
\hline & & B & NS & NS & NS & NS \\
\hline & & $\mathrm{A} * \mathrm{~B}$ & NS & NS & NS & NS \\
\hline \multirow{9}{*}{$\begin{array}{l}\text { SPAD } \\
\text { value }\end{array}$} & \multirow{3}{*}{ PE } & col.1 & $35.5 \pm 2.0 \mathrm{a}$ & $36.4 \pm 3.6 \mathrm{~b}$ & $34.1 \pm 3.4 \mathrm{~d}$ & $35.1 \pm 2.8 \mathrm{c}$ \\
\hline & & $\mathrm{col} .2$ & $36.5 \pm 2.1 \mathrm{a}$ & $38.2 \pm 0.2 \mathrm{~b}$ & $35.5 \pm 0.6 \mathrm{~d}$ & $35.2 \pm 9.0 \mathrm{c}$ \\
\hline & & col.3 & $34.2 \pm 2.4 \mathrm{a}$ & $40.1 \pm 0.8 \mathrm{ab}$ & $42.8 \pm 3.8 \mathrm{bc}$ & $48.2 \pm 3.8 \mathrm{ab}$ \\
\hline & \multirow{3}{*}{$\mathrm{PO}$} & col.1 & $36.4 \pm 4.1 \mathrm{a}$ & $41.0 \pm 1.5 \mathrm{ab}$ & $37.2 \pm 1.3 \mathrm{~cd}$ & $39.4 \pm 2.9 \mathrm{bc}$ \\
\hline & & $\operatorname{col} .2$ & $37.4 \pm 2.2 \mathrm{a}$ & $39.7 \pm 4.5 \mathrm{ab}$ & $48.4 \pm 5.5 \mathrm{ab}$ & $39.7 \pm 7.4 \mathrm{bc}$ \\
\hline & & $\operatorname{col} .3$ & $35.1 \pm 1.2 \mathrm{a}$ & $44.7 \pm 2.4 \mathrm{a}$ & $49.3 \pm 1.6 \mathrm{a}$ & $54.3 \pm 2.8 \mathrm{a}$ \\
\hline & \multirow{3}{*}{ F-test } & A & NS & $*$ & $* * *$ & NS \\
\hline & & B & NS & NS & $* * *$ & $* *$ \\
\hline & & A*B & NS & NS & NS & NS \\
\hline
\end{tabular}

${ }^{\text {ZMean }} \pm$ S.D. values in the same row (a-c) followed by different letters are significantly different according to Duncan's multiple range test $(p<0.05)$. ${ }^{\mathrm{y}} \mathrm{NS}, *, * * * * *$ stands for Nonsignificant or significant at $p<0.05,0.01$ or 0.001 respectively. 


\section{3. 생육량 및 수확량 비교}

\section{1 생육조사 결과}

온실내부 북쪽 측면(Col. 1), 중앙(Col. 2), 남쪽 측면(Col. 3) 에 위치한 재배열에 따라, $\mathrm{PE}$ 필름과PO필름 피복재에 따른 단
동온실의 생육조사 결과는 다음과 같다. 단동온실에서 초장의 경우 $\mathrm{PE}$ 필름과 $\mathrm{PO}$ 필름 처리에 의한차이는 없었고, 엽수의 경 우 정식 후 133 일 조사구에서 $\mathrm{PE}$ 필름의 재배열 북쪽 측면 $(\mathrm{Col}$. 1) 보다 중앙(Col. 2) 또는 남쪽 측면(Col. 3)에서 유의성 있게

Table 3. Tomato growth status in double span greenhouse.

\begin{tabular}{|c|c|c|c|c|c|c|}
\hline \multirow{2}{*}{ Item } & \multicolumn{2}{|c|}{ Treatment } & \multicolumn{4}{|c|}{ Days after planting (Date) } \\
\hline & A & B & $21\left({ }^{\prime} 19.12 .24\right)$ & $64(' 20.2 .5)$ & 106 ('20.3.18) & 133 ('20.4.14) \\
\hline \multirow{11}{*}{$\begin{array}{l}\text { Plant } \\
\text { height } \\
(\mathrm{cm})\end{array}$} & \multirow{4}{*}{ PE } & col.1 & $29.3 \pm 6.1 \mathrm{~b}^{\mathrm{z}}$ & $135.0 \pm 18.0 \mathrm{ab}$ & $258.3 \pm 29.0 \mathrm{a}$ & $286.0 \pm 16.0 \mathrm{~b}$ \\
\hline & & col. 2 & $29.0 \pm 3.6 \mathrm{~b}$ & $133.3 \pm 14.5 \mathrm{ab}$ & $247.3 \pm 19.6 \mathrm{a}$ & $295.5 \pm 12.2 \mathrm{ab}$ \\
\hline & & col.3 & $32.6 \pm 4.9 \mathrm{ab}$ & $128.3 \pm 2.8 \mathrm{~b}$ & $236.3 \pm 11.9 \mathrm{a}$ & $302.6 \pm 32.3 \mathrm{ab}$ \\
\hline & & col.4 & $31.0 \pm 2.6 \mathrm{ab}$ & $131.6 \pm 1.5 \mathrm{ab}$ & $236.0 \pm 11.5 \mathrm{a}$ & $302.0 \pm 28.1 \mathrm{ab}$ \\
\hline & \multirow{4}{*}{$\mathrm{PO}$} & col.1 & $34.1 \pm 2.0 \mathrm{ab}$ & $148.0 \pm 19.2 \mathrm{ab}$ & $234.0 \pm 51.8 \mathrm{a}$ & $284.6 \pm 53.1 \mathrm{~b}$ \\
\hline & & $\operatorname{col} .2$ & $31.3 \pm 1.1 \mathrm{ab}$ & $143.6 \pm 10.9 \mathrm{ab}$ & $230.0 \pm 22.2 \mathrm{a}$ & $283.0 \pm 28.0 \mathrm{~b}$ \\
\hline & & col.3 & $38.0 \pm 2.0 \mathrm{a}$ & $143.6 \pm 19.3 \mathrm{ab}$ & $223.0 \pm 31.5 \mathrm{a}$ & $277.0 \pm 33.1 \mathrm{~b}$ \\
\hline & & col.4 & $36.0 \pm 4.0 \mathrm{ab}$ & $155.6 \pm 1.1 \mathrm{a}$ & $269.0 \pm 8.5 \mathrm{a}$ & $346.3 \pm 9.2 \mathrm{a}$ \\
\hline & \multirow{3}{*}{ F-test ${ }^{y}$} & A & $* *$ & $*$ & NS & NS \\
\hline & & B & NS & NS & NS & NS \\
\hline & & $\mathrm{A} * \mathrm{~B}$ & NS & NS & NS & NS \\
\hline \multirow{11}{*}{$\begin{array}{l}\text { No. of } \\
\text { leaves }\end{array}$} & \multirow{4}{*}{$\mathrm{PE}$} & col.1 & $10.0 \pm 1.0 \mathrm{~b}$ & $24.0 \pm 0.0 \mathrm{a}$ & $32.6 \pm 3.5 \mathrm{~b}$ & $41.5 \pm 0.5 \mathrm{a}$ \\
\hline & & col. 2 & $11.0 \pm 1.0 \mathrm{ab}$ & $25.3 \pm 1.1 \mathrm{a}$ & $36.3 \pm 0.5 \mathrm{ab}$ & $44.3 \pm 1.5 \mathrm{a}$ \\
\hline & & col.3 & $11.0 \pm 1.0 \mathrm{ab}$ & $25.0 \pm 0.0 \mathrm{a}$ & $34.3 \pm 0.5 \mathrm{~b}$ & $43.3 \pm 0.5 \mathrm{a}$ \\
\hline & & col.4 & $11.0 \pm 1.0 \mathrm{ab}$ & $24.6 \pm 1.5 \mathrm{a}$ & $35.0 \pm 1.0 \mathrm{ab}$ & $43.0 \pm 2.0 \mathrm{a}$ \\
\hline & \multirow{4}{*}{$\mathrm{PO}$} & col.1 & $11.6 \pm 0.5 \mathrm{ab}$ & $24.6 \pm 2.5 \mathrm{a}$ & $34.3 \pm 3.7 \mathrm{~b}$ & $40.6 \pm 4.9 \mathrm{a}$ \\
\hline & & col. 2 & $11.6 \pm 0.5 \mathrm{ab}$ & $24.6 \pm 0.5 \mathrm{a}$ & $33.6 \pm 1.5 \mathrm{~b}$ & $42.0 \pm 2.6 \mathrm{a}$ \\
\hline & & col.3 & $12.0 \pm 1.0 \mathrm{a}$ & $26.3 \pm 1.5 \mathrm{a}$ & $35.3 \pm 1.5 \mathrm{ab}$ & $44.0 \pm 0.0 \mathrm{a}$ \\
\hline & & col.4 & $12.0 \pm 1.0 \mathrm{a}$ & $25.6 \pm 2.0 \mathrm{a}$ & $38.6 \pm 2.5 \mathrm{a}$ & $44.0 \pm 1.0 \mathrm{a}$ \\
\hline & \multirow{3}{*}{ F-test } & A & $*$ & NS & NS & NS \\
\hline & & B & NS & NS & NS & NS \\
\hline & & $\mathrm{A} * \mathrm{~B}$ & NS & NS & NS & NS \\
\hline \multirow{11}{*}{$\begin{array}{l}\text { SPAD } \\
\text { value }\end{array}$} & \multirow{4}{*}{ PE } & col.1 & $33.4 \pm 0.1 \mathrm{a}$ & $35.2 \pm 0.2 \mathrm{~b}$ & $37.8 \pm 3.2 \mathrm{a}$ & $39.8 \pm 3.8 \mathrm{c}$ \\
\hline & & col. 2 & $34.5 \pm 2.7 \mathrm{a}$ & $36.1 \pm 3.6 \mathrm{ab}$ & $39.8 \pm 3.6 \mathrm{a}$ & $40.8 \pm 7.0 \mathrm{bc}$ \\
\hline & & col.3 & $33.9 \pm 1.4 \mathrm{a}$ & $40.6 \pm 4.3 \mathrm{ab}$ & $39.5 \pm 4.0 \mathrm{a}$ & $45.0 \pm 5.6 \mathrm{abc}$ \\
\hline & & col.4 & $32.2 \pm 1.9 \mathrm{a}$ & $37.4 \pm 1.1 \mathrm{ab}$ & $45.3 \pm 5.0 \mathrm{a}$ & $45.6 \pm 7.0 \mathrm{abc}$ \\
\hline & \multirow{4}{*}{ PO } & col.1 & $33.8 \pm 0.6 \mathrm{a}$ & $36.4 \pm 3.8 \mathrm{ab}$ & $42.8 \pm 5.6 \mathrm{a}$ & $53.7 \pm 7.4 \mathrm{ab}$ \\
\hline & & col. 2 & $32.9 \pm 1.3 \mathrm{a}$ & $42.0 \pm 7.3 \mathrm{ab}$ & $46.4 \pm 3.5 \mathrm{a}$ & $54.1 \pm 5.0 \mathrm{a}$ \\
\hline & & col.3 & $32.6 \pm 1.7 \mathrm{a}$ & $43.5 \pm 2.3 \mathrm{a}$ & $45.3 \pm 4.3 \mathrm{a}$ & $51.0 \pm 10.8 \mathrm{abc}$ \\
\hline & & col. 4 & $32.0 \pm 0.8 \mathrm{a}$ & $36.6 \pm 5.1 \mathrm{ab}$ & $44.1 \pm 6.0 \mathrm{a}$ & $41.7 \pm 4.4 \mathrm{abc}$ \\
\hline & \multirow{3}{*}{ F-test } & A & NS & NS & $*$ & $*$ \\
\hline & & B & NS & NS & NS & NS \\
\hline & & $A * B$ & NS & NS & NS & NS \\
\hline
\end{tabular}

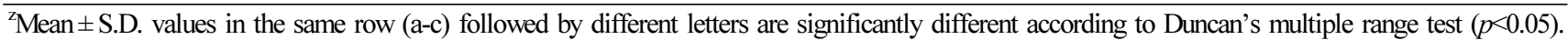
${ }^{\mathrm{y}} \mathrm{NS}, *, * *, * * *$ stands for Nonsignificant or significant at $p<0.05,0.01$ or 0.001 respectively 
높았다. 단동온실에서는 수량과 과실 품질에 영향을 미칠 수 있는 엽록소 지수(SPAD Value)가 필름처리 및 재배열의 위치 에 따라 처리간에 매우 높은 유의성을 나타냈다(Table 2). 특히 $\mathrm{PO}$ 필름을 사용한 단동온실 남쪽 측면 재배열에서 엽록소 지 수가 54.3으로 가장 높았다. 참외의 경우 광 요구도가 높은 작 물로 광 투과율이 저하하는 조건에서 엽록소 함량이 감소하는 경향이 있다는 보고가 있다(Lee 등, 2003; Shin 등, 2016). 이 와 같이 PO필름 온실의 남쪽 측면(col 3)에 위치한 재배열이 토마토 생장에 매우 유리한 것으로 판단된다. 연동온실의 생육 조사결과는 Table 3 과 같다. 초장과 엽수의 경우 $\mathrm{PO}$ 필름 재배 시 조금 더 좋은 결과를 보였으나 큰 유의성은 없었고, 단동온 실 결과와마찬가지로 엽록소 지수의 경우 정식 후 133 일 조사 구에서 $\mathrm{PO}$ 필름 처리 시 높은 값을 나타내었고, 특히 $\mathrm{PE}$ 필름 Col. 1 재배열은 연동온실에서 가장 중심에 위치한 부분으로 서 엽록소 지수가 39.8 로 가장 저조한 값을 나타내었다.

\section{2 수확량 조사 결과}

수확량 조사를 시험 기간 동안 7 차례에 걸쳐 5 화방까지 수 행하였으며 수량조사는 생육조사 지점의 첫번째 조사주에서 수확한(단동 9 주, 연동 12 주)과실만의 중량을 합하여 총중량 으로 계산하였으며 그루당, 단위면적당 수확량 및 재식밀도 는 Table 4,5 와 같다.

또한 $\mathrm{PE}$ 및 $\mathrm{PO}$ 필름 시험온실에서 각각 수확한 1 주당 수확 량을 서로 비교한 결과 단동온실은 Fig. 18과같이 나타났으며 $\mathrm{PO}$ 필름 온실이 $\mathrm{PE}$ 필름 온실 대비 11 일 정도 수확시기가 빨 라졌으며 수량은 $20 \%$ 증대된 것으로 조사되었다. 연동온실 은 Fig. 19 와 같이 나타났으며 $\mathrm{PO}$ 필름 온실이 PE필름 온실 대비 14 일 정도 수확시기가 빨라지고 수량은 $9 \%$ 증대된 것으
로 조사되었다. 참외 피복필름 연구에서 $\mathrm{PE}$ 필름 처리에 비해 $\mathrm{PO}$ 필름 처리구에서 첫 수확 소요일수가 7일 촉진되었고, 과 중이 더 높은 결과와 같았다(Shin 등, 2016). 또한 $\mathrm{PO}$ 필름 처 리의 경우 적외선 흡수율이 높을수록 초기 수량이 증가한다는 연구결과와 일치한다(Choi 등, 2007; Shin 등, 2016). 단동온 실과 연동온실 각각 4월 14 일과 4월 22일 수량은 PE 필름 처 리에서 증가한 것으로 나타났으나 이는 토마토 화방을 적과 조정을 하지 않고 방임한 결과로 판단된다.

\section{4. 연료소비량 비교}

2019년 12월 3일부터 2020년 4월30일까지의 연료소비량 을 측정한 결과 단동온실이며 $\mathrm{PE}$ 필름 피복 온실의 연료소비 량은 2,310L(liter)이었으며 $\mathrm{PO}$ 필름 단동 온실의 연료소비량 은 $2,024 \mathrm{~L}$ (liter)로 측정되었다. 연동온실이며 PE필름 피복온 실의 연료소비량은 $5,127 \mathrm{~L}$ (liter)이며 $\mathrm{PO}$ 필름 피복온실의 연 료소비량은 4,539L(liter)로 측정되었다. 연료소비량을 등유 $1 \mathrm{~L}$ 당 총발열량인 $36.7 \mathrm{MJ}(8,770 \mathrm{kcal})$ 로 환산하면 단동온실 에서의 $\mathrm{PE}$ 필름, $\mathrm{PO}$ 필름 피복온실의 난방에너지 소비량은 $84,777 \mathrm{MJ}, 74,281 \mathrm{MJ}$ 로 나타났으며 연동온실의 $\mathrm{PE}$ 필름, $\mathrm{PO}$ 필름 피복온실의 난방에너지 소비량은 $188,161 \mathrm{MJ}, 166.581$ $\mathrm{MJ}$ 로 산정되었다, 연료소비량을 $\mathrm{PE}$ 필름을 기준으로 하여 $\mathrm{PO}$ 필름의 에너지 절감효과를 산정한 결과 단동온실에서는 $12.4 \%$ 가 절감되었고 연동온실에서는 $11.5 \%$ 가 절감된 것으 로 나타났다. 이러한 결과로부터 $\mathrm{PO}$ 필름을 이중 피복으로 설 치하였을 때 $\mathrm{PE}$ 필름보다 보온성이 우수한 것으로 판단되었 으며 시설채소온실의 $80 \%$ 이상을 차지하고 있는 단동 온실에 서 $\mathrm{PO}$ 필름이 피복재로 사용된다면 상당한 양의 난방에너지 를 절감 할 수 있을 것으로 판단되었다.

Table 4. Yield analysis for PE, PO covering film in a single span greenhouse.

\begin{tabular}{ccccc}
\hline \hline \multirow{2}{*}{ Treatment } & $\begin{array}{c}\text { Total yield } \\
\text { (g/9plant) }\end{array}$ & $\begin{array}{c}\text { Yield }(\mathrm{g}) \text { per } \\
1 \text { plant }\end{array}$ & $\begin{array}{c}\text { Yield }(\mathrm{g}) \text { per } \\
\text { unit area }\left(\mathrm{m}^{2}\right)\end{array}$ & $\begin{array}{c}\text { Planting density } \\
\text { (row spacing }(\mathrm{cm}) \times \text { plant spacing }(\mathrm{cm}))\end{array}$ \\
\hline PE film (B23) & 27,641 & 3,071 & 2,924 & $190 \times 40$ \\
PO film (B21) & 33,187 & 3,687 & 3,511 & $190 \times 40$ \\
\hline
\end{tabular}

Table 5. Yield analysis for PE, PO covering film in double span greenhouse.

\begin{tabular}{ccccc}
\hline \hline \multirow{2}{*}{ Treatment } & Total yield & \multicolumn{2}{c}{ Yield per unit } & \\
\cline { 3 - 4 } & $(\mathrm{g} / 12$ plant $)$ & $\begin{array}{c}\text { Yield }(\mathrm{g}) \text { per } \\
1 \text { plant }\end{array}$ & $\begin{array}{c}\text { Yield }(\mathrm{g}) \text { per } \\
\text { unit area }\left(\mathrm{m}^{2}\right)\end{array}$ & $\begin{array}{c}\text { Planting density } \\
\text { (row spacing }(\mathrm{cm}) \times \text { plant spacing }(\mathrm{cm}))\end{array}$ \\
\hline PE film (B15) & 24,347 & 2,028 & 2,958 & $160 \times 40$ \\
PO film (B16) & 26,413 & 2,201 & 3,209 & $160 \times 40$ \\
\hline
\end{tabular}




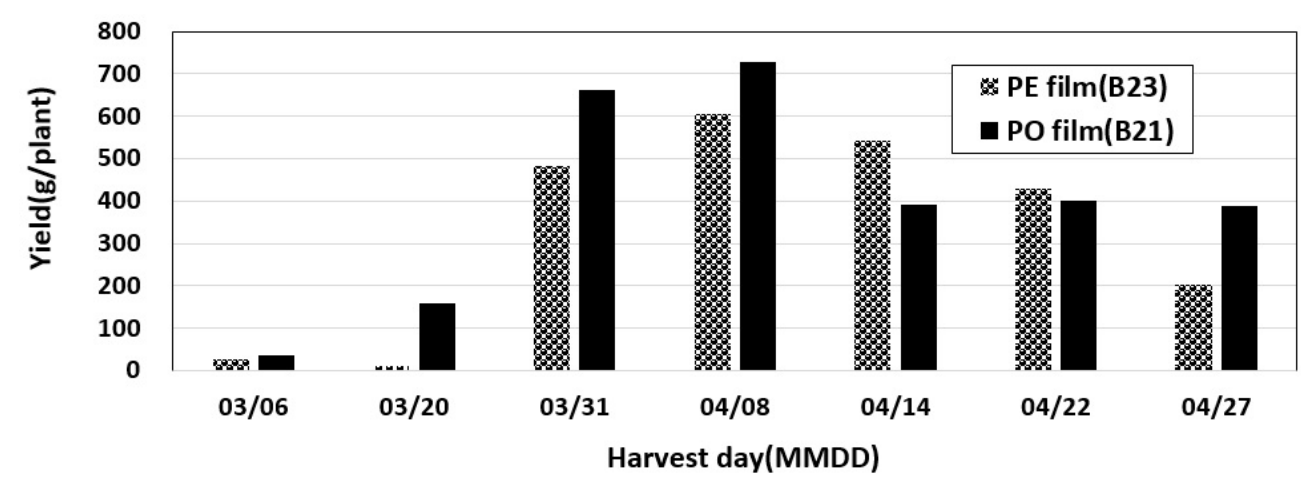

Fig. 18. Yield comparison for each covering film on harvest day in a single span greenhouse.

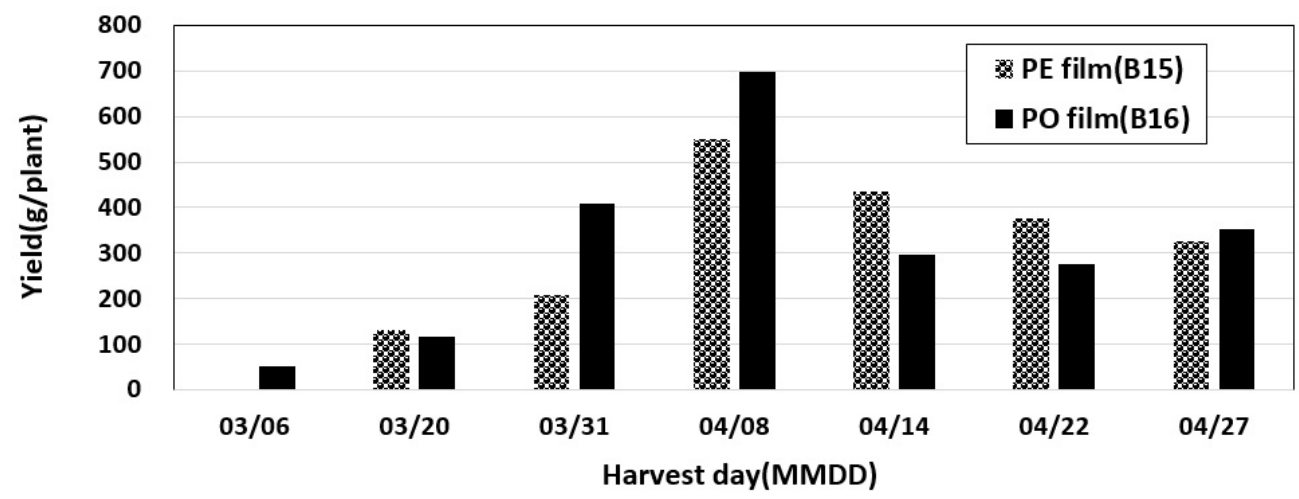

Fig. 19. Yield comparison for each covering film on harvest day in double span greenhouse.

\section{적 요}

본 연구는 $\mathrm{PO}$ 필름과 $\mathrm{PE}$ 필름을 온실의 피복재로 적용하였 을 때 작물 수량 증대 및 에너지 절감에 미치는 영향을 조사하 였다. 시험온실은 국립원예특작과학원 시설원예연구소 내에 위치한 단동온실(1-1W) 2동(B21, B23)과 2연동온실(1-2W 형) 2 동(B15, B16)을 사용하였다. 단동온실의 규격은 폭 $7.2 \mathrm{~m}$, 길이 $30 \mathrm{~m}$, 측고 $1.5 \mathrm{~m}$, 동고 $3.6 \mathrm{~m}$ 이고, 연동온실의 규 격은 폭 $8 \mathrm{~m}$, 길이 $40 \mathrm{~m}$, 측고 $3.1 \mathrm{~m}$, 동고 $5.8 \mathrm{~m}$ 의 온실로서 이 중 골조로 된 아치형 표준온실이다. 동절기 시험을 위하여 $\mathrm{PO}$ 필름(외피 $0.15 \mathrm{~mm}$, 내피 $0.10 \mathrm{~mm}$ )을 단동과 연동의 온실 피 복재로 사용하였으며 대조구 온실로서 $\mathrm{PE}$ 필름 $($ 외피 $0.15 \mathrm{~mm}$, 내피 $0.10 \mathrm{~mm}$ )을 단동과 연동에 설치하였다. 시험작물은 완 숙토마토 ‘해피니스’를 토양재배 하였고 2019년 12월 3일에 정식하여 2020년 4월 30 일까지 재배하였다. 온실내부 야간 설정온도는 $15^{\circ} \mathrm{C}$ 를 유지하였으며 주간에는 $23 \sim 24^{\circ} \mathrm{C}$ 를 유 지할수 있도록 측창 및 천창을 개방하였다. $\mathrm{PO}$ 필름의 단동 및 연동온실 내부에서의 일사량, 온습도 등을 측정하였고, 재배 기간 동안의 생육량을 조사하였으며 에너지 절감 효과를 조사 하기 위해 피복재별 시험온실의 온풍난방기 연료 소비량을 조
사하였다. 조사 결과 단동온실에서의 일사량은 $\mathrm{PO}$ 필름 온실 에서 $\mathrm{PE}$ 필름 온실보다 $7 \%$ 증가하였고 수확량은 $20 \%$ 증대되 었다. 연동온실에서의 일사량은 $\mathrm{PO}$ 필름 온실에서 $\mathrm{PE}$ 필름 온 실보다 $11 \%$ 증가되었고, 수확량은 $9 \%$ 증가하였다. 또한 온 실내부의 일평균 온습도 측정 결과 단동온실은 $\mathrm{PE}, \mathrm{PO}$ 필름 온실이 $19.0^{\circ} \mathrm{C}, 19.1^{\circ} \mathrm{C}$, 상대습도 $75 \%$ 를 나타냈고 연동온실 은 $\mathrm{PO}$ 필름 온실이 $19.6^{\circ} \mathrm{C}$, 상대습도 $57 \%$ 를 나타냈고 $\mathrm{PE}$ 필 름 온실이 $18.8^{\circ} \mathrm{C}$, 상대습도 $63 \%$ 를 나타냈다. 연료 소비량은 단동온실의 $\mathrm{PO}$ 필름 온실이 $\mathrm{PE}$ 필름 온실보다 $12.4 \%$ 절감되 었고 연동온실에서는 $\mathrm{PO}$ 필름 온실이 $\mathrm{PE}$ 필름 온실보다 $11.5 \%$ 절감된 것으로 나타났다.

추가 주제어 :일사량 증대, 보온 효과, 난방비 절감

\section{사 사}

본 연구는 농촌진흥청 국립원예특작과학원 연구개발사업 (과제번호:PJ013489012020)의 지원에 의해 이루어진 것임. 


\section{Literature Cited}

Challa, H. and A.H.C.M. Schapendonk. 1984. Quantification of effects of light re-duction in greenhouses on yield. Acta Hortic 148:501-510.

Choi, Y.J., H. Chun, H.J. Kim, S.Y. Lee, S.H. Yum, Y.H. Choi, Y.S. Shin, and D.S. Jeong. 2007. Nutritional components content of oriental melon fruits cultivated under different greenhouses covering films. J. Bio-Env. Con. 16:72-77 (in Korean).

Cockshull, K.E., C.J. Graves, and C.R.J. Cave. 1992. The influence of shading on yield of glasshouse tomatoes. J Hortic Sci 67:11-24.

Jin, B.O., H.K. Kim, Y.S. Ryou, T.S. Lee, Y.H. Kim, S.S. Oh, J.P. Moon and G.C. Kang, 2018. Comparative Analysis of Thermal Performance According to Combines of Multilayer Insulating Curtain. Journal of the Korean Society of Mechanical Technology 20:763-769 (in Korean).

Jin, B.O., H.K. Kim, Y.S. Ryou, T.S. Lee, Y.H. Kim, S.S. Oh and G.C. Kang, 2019. Analysis of Heat Transfer Characteristics on Multi-layer Insulating Curtains Coated with Slica Aerogel. Proteced Horticulture and Plant Factory. 28:273-278 (in Korean).

Kwon, J. K., K.S. Park, H.G. Choi, S.Y. Lee, K Bekhzod and N.J. Kang, 2012, Effect- of Polyolefine Greenhouse Covering Film on Growth of Lettuce and Cucum-ber in Cool Season Cultivation. Journal of Bio-Environment Control 21:312-316 (in Korean).

Lee, H.W., S. Diop, and Y.S. Kim. 2011. Variation of the overall heat transfer c-oefficient of plastic greenhouse covering material. J. Bio-Environ. Control 20:72-77 (in Korean).

Lee, S.G., Y.C. Kim, T.C. Seo, Y.G. Kang, H.K. Yun and H.D. Suh. 2003. Effects of low light intensity after fruit set on growth and quality of oriental melon. J Kor Soc Hort Sci 44:31-34 (in Korean).

Ministry of Agriculture, Food and Rural Affairs (MAFRA). 2019. The status of greenhouse and vegetable producition in 2018 ed. Sejong, Korea (in Korean).

National Institute of Agricultural Sciences. 2010. New Agricultural Energy Saving Tec-hnology.p. 126 (in Korean).

National Institute of Agricultural Sciences. 2017. Prescription criteria for fertilizer use by crop. 3rd edition. p. 66 (in Korean).

Rural Development Administration, National Institute of Agricultural Sciences. 2015. Design standards for greenhouse environment, Wanju, Jeollabukdo, Korea (in Korean).

Ryou, Y.S., Y.K. Kang, Y.J. Kim and K.C. Kang, 2008. Heating and Cooling Effect of Protected Horticulture by Geothermal Heat Pump System with Horizontal Heat Exchanger. Proceedings of the 2008 spring annual conference of The Korean society for New and Renewable Energy. p. 630-633 (in Korean).

Shin, Y.S., H.W. Do, I.K. Yeon, S.K. Choi, and B.S. Choi. 1999. Effect thermokee-ping-water bag on growth, fruit quality and yield of oriental melon. J Bio-Env Con 8:67-73 (in Korean).

Shin, Y.S., I.K. Yeon, J.E. Lee, J.D. Cheung, S.Y. Choi, and D.S. Chung. 2009. Ef-fect of long period usage of polyolefin film on growth and fruit quality in Korea melon. J Bio-Env Con 18:9-14 (in Korean).

Shin, Y.S., J.E. Lee, H.W. Do, H. Chun, and D.S. Chung. 2016. Effect of polyolef-in film on korean melon quality and industry. J Bio-Env Con 25:95-99 (in Korean).

Yun, S.W., S.Y. Lee, D.H. Kang, J.K. Son, M.J. Park, H.T. Kim and D.K. Choi, 2019, Comparison of Thermal Insulation of Multi-Layer Thermal Screens for Greenhouse: Results of Hot-Box Test. Proteced Horticulture and Plant Factory. 28:255-264 (in Korean). 